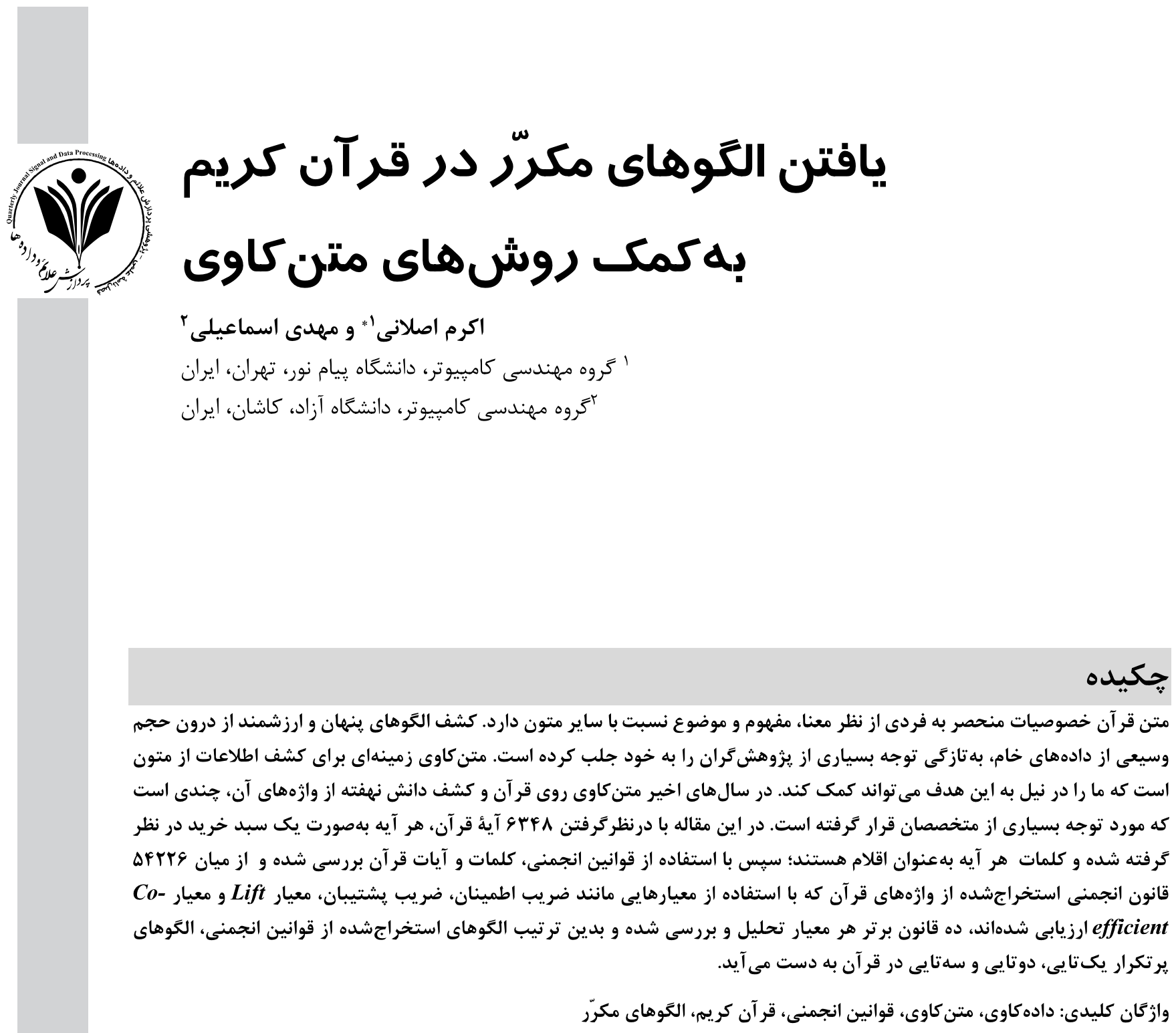

\title{
Finding Frequent Patterns in Holy Quran UsingText Mining
}

\author{
Akram aslani ${ }^{*}$ \& Mahdi esmaeili ${ }^{2}$ \\ ${ }^{1}$ Department of Computer Engineering, Payam Noor University, Tehran, Iran \\ ${ }^{2}$ Department of Computer Engineering, Azad University, Kashan, Iran
}

\begin{abstract}
Quran's Text differs from any other texts in terms of its exceptional concepts, ideas and subjects. To recognize the valuable implicit patterns through a vast amount of data has lately captured the attention of so many researchers. Text Mining provides the grounds to extract information from texts and it can help us reach our objective in this regard. In recent years, Text Mining on Quran and extracting implicit knowledge from Quranic words have been the object of researchers' focus. It is common that in Quranic experts' arguments, different sides of the discussion present different intellectual, logical and some non-integrated minor evidence in order to prove their own theories. More often than not, every side of these arguments disapproves of the other's hypothesis and in the end it is impossible for them to reach a state of consensus on the matter, the reason is that, they do not have a common basis for their arguments and they do not make use of scientific, logical methods to strongly support their theories. Therefore, using modern technological trends regarding Quranic arguments could lead to resolving so many of current discrepancies, caused by human errors, which exist among Quranic researchers. It can help providing a common ground for their arguments in order to reach a comprehensive understanding.

The method used in this research implements frequent pattern mining algorithms, singular frequent patterns as well as dual and tripe frequent patterns in order to analyze Quranic text, in addition to this, Association rules have also been evaluated in the research.
\end{abstract}

Corresponding author

* نويسندة عرهدهار مكاتبات 
Out of 54226 extracted association rules for Quranic words which have been evaluated by the use of criteria such as confidence coefficient, support coefficient, lift criteria as well as Co-efficient criteria. Top 10 rules for each criterion have been analyzed and reviewed throughout the project.

Keywords: Data Mining, Text Mining, Association rules, Holy Quran, Frequent patterns

اما در متن كاوى كاربر فقط بر موضوع مورد نظر خود متمركز

قرآن مجيد، برترين و آخرين پييام خداوند و بزرگترين

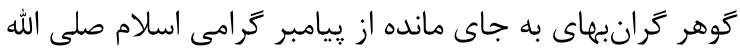

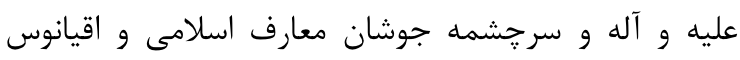

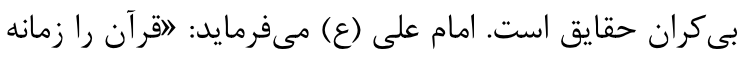

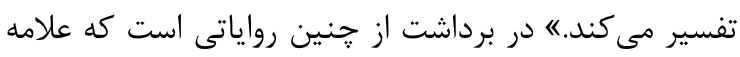

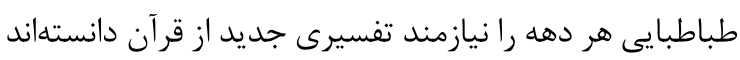
و بديهى است اين مهمم مستلزم بهرهمندى از فناورىهاى دهاى ريازئن

معاصر است [5].

قرآن شامل موضوعات زيادى بوده و براى استفاده

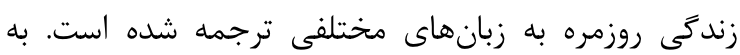

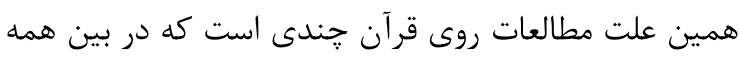

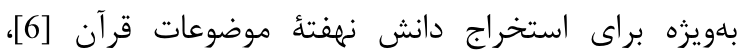

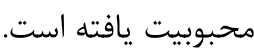

در اين خصوص به كارگيرى متن كاوى در زيردازش

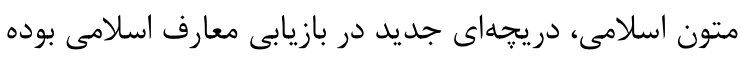

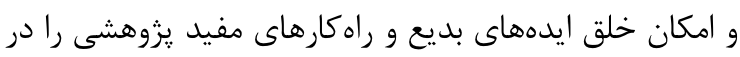
ذهن مخاطبان ايجاد خواهد كرد. همرجنين تحول اساسى راهى راه

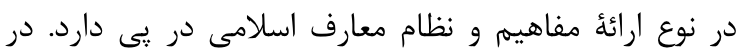

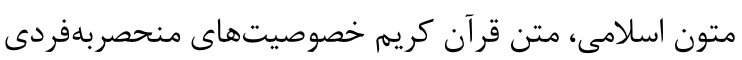

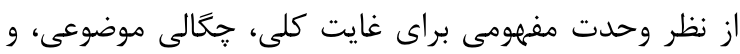

دانهبندى در مقايسه با ساير متون دارد [7].

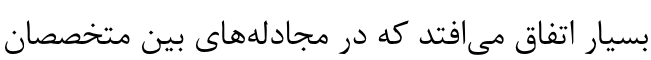

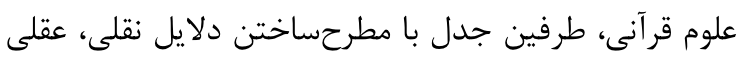

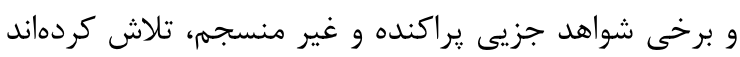

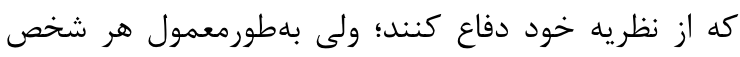

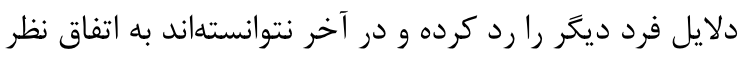

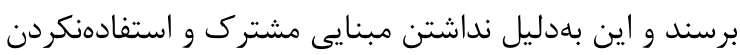

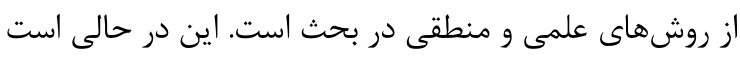

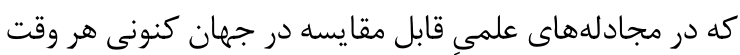

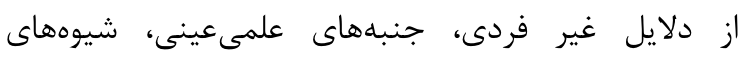
تجربه هذير و بهخصوص فناورىهاى نوين استفاده شده، اين

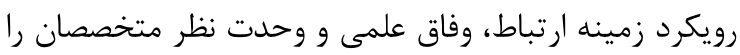

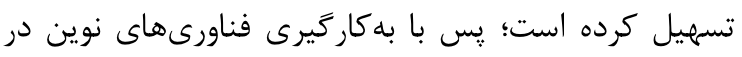

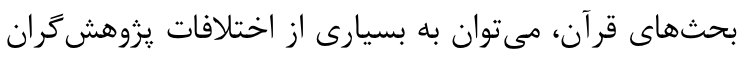

- مقدمه

فناوري مديريت ِيايخاهدادههاي ِيشرفته انواع مختلفى از

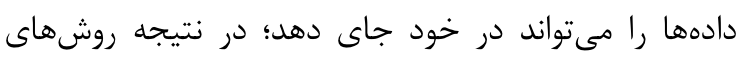

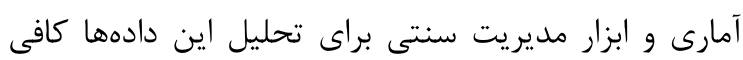

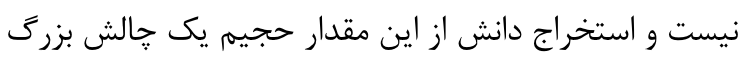
تلقى مىشود. داده كاوى كوششى براى بهدست آوردن اطلاعات

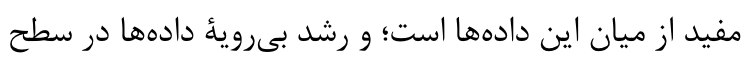

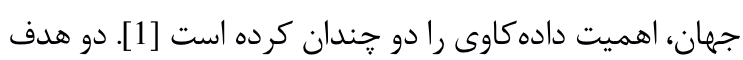

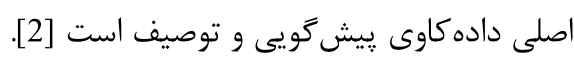

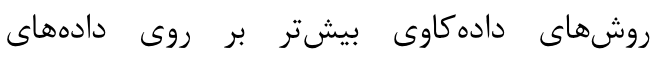

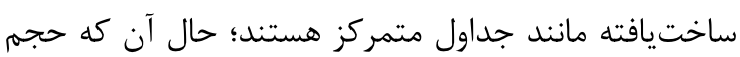
وسيعى از اطلاعات در دسترس، در دنياى بيرون در خاييخاهداده

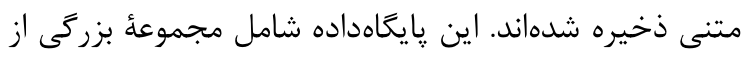
مستندات متنى مانند كتابها، مقالات، كتابخانههاى ديجيتال و صفحات وب هستند. امروزه بسيارى از سازمانها اطلاعات

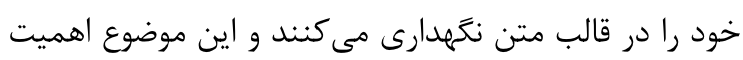
استفاده از روشهاى دادهاوى راد راب براى اين نوع از دادهنها

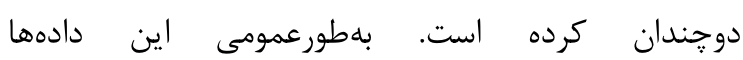

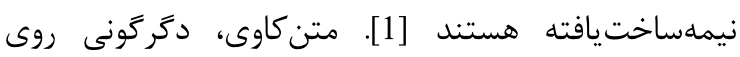

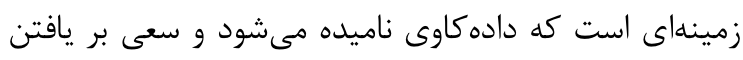

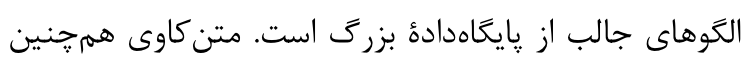
بهعنوان تحليل هوشمند متن، شناخته مىشود. متن كاوى يا

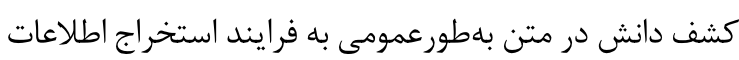

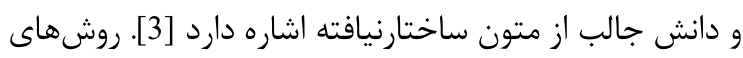

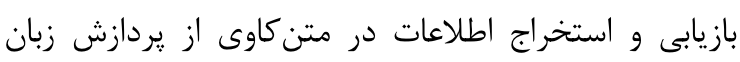

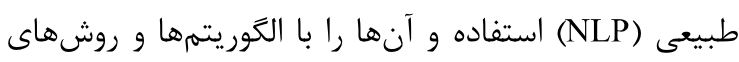

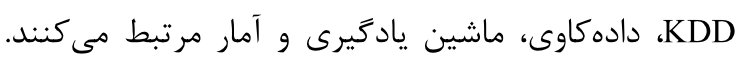

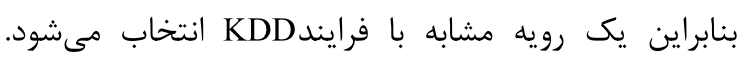

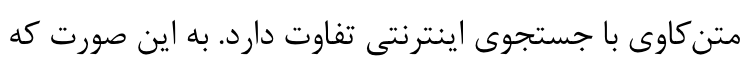
در جستجوى اينترنتى كاربر بلهنبال هيزهايى است كه درى درقبل

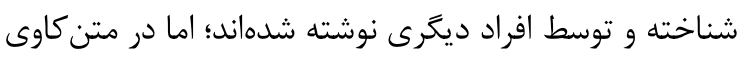
هدف كشف اطلاعاتى است كه درقبل ناشناخته بوده و و موضوعاتى هستند كه هنوز كسى آنها را به رشته تحرير در

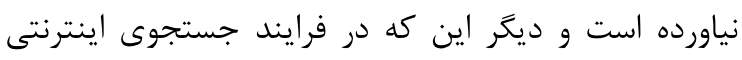

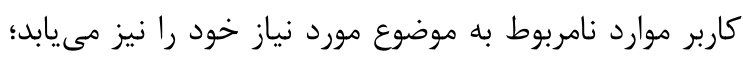


شماى وزندار استفادهشه TF/IDF است. از VI لخش، بخش "Allah" و "Wohamad" و "Wahai " بالاترين تكرار را در شش سوره داشتند. با استفاده ازآستانه ضريب اطمينان

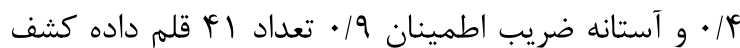
شدند و تعداد Dم قانون انجمنى توليد شدند. درنهايت تعداد

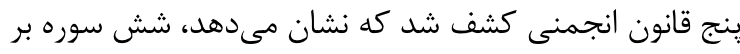
حضرت محمد(ص) نازل شده تا به بشريت يادآورى كند "الله"

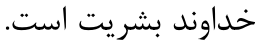

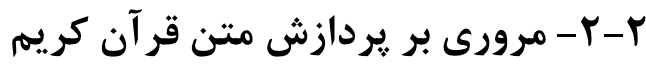
يروهش [10] با عنوان يردازش متن قرآن كريم يزوهشى در ير فر

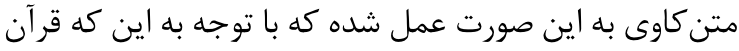

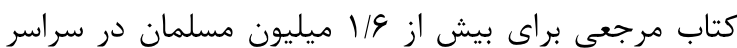
جهان است؛ به همين سبب استخر اج اطلاعات و دانش ازي از قرآ آن،

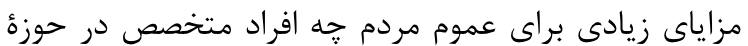

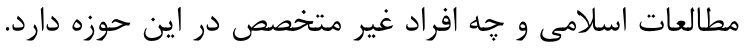

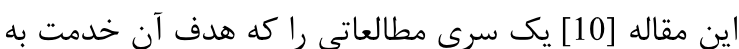
قرآن و فراهمركرن خدمات و اطلاعات و دانش صحيح به همه

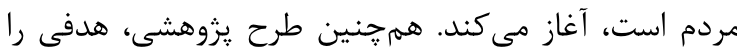

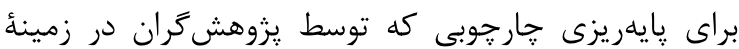

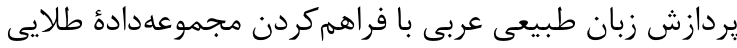
تنها با روشهاى مفيد و اطلاعاتى كه بلهعلاوه به اين زمينه اضافه خواهد شد، بررسى مى كند. هدف دئ اين مقاله ييداكردن رويكردى براى تحليل متن عربى و سيس ارائه

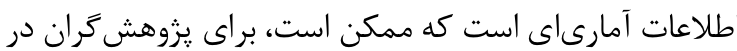

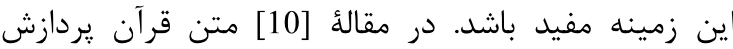

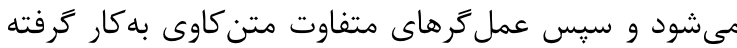

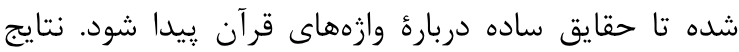

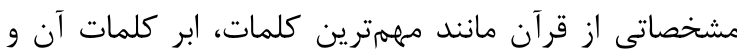
سورههايى با تكرار وازه بالا را نشان مى دهدد. همدة اين نتايج

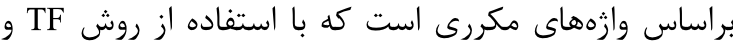
TF/IDF

r-r- كاربرد الكوريتم دادهكاوى براى يافتن

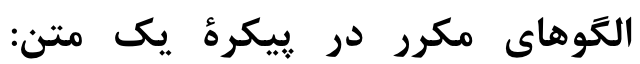

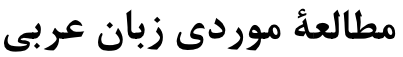

يزوهش [11] كاربرد يك الكَريتم دادهاوى بران براى يافتن

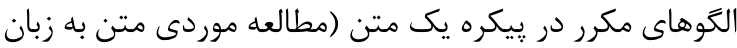

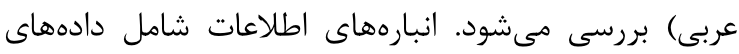

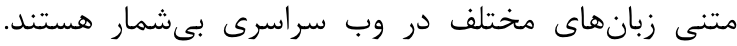
ييكرههاى ديجيتال متون مقدس اسلامى وابسته به قرآنان
قرآنى كه بهطورمعمول ناشى از خطاى انسانى آنهاست، پِايان داد و مبنايى مشترك براى آنها بهدست آورد [8 آنسائ.


است؛ بهكونهاى كه ارتباط بين الفاظ وكلمات در هر آئ دئ

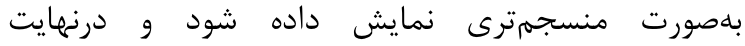
خروجىهاى بهدستآمده بتواند يزوهشكران ران ران در حوزء يزوهشهاى قرآنى يارى رساند.

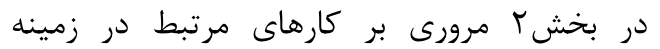

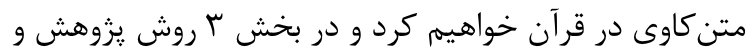

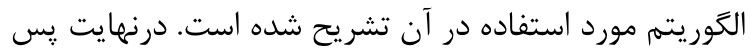

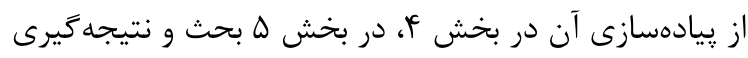

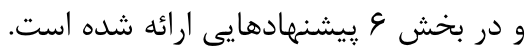

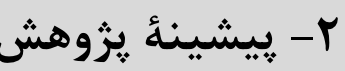

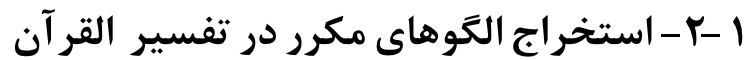
يروهش [9] الكوهاى مكررى را بررسى مى كند كه مى توانند در سورههاى قرآن كه به زبان مالايى (زبان كشور ماكي مالزى)

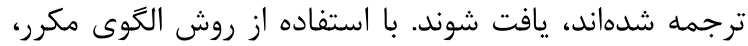
الكوهاى مهم و روابط جالب در سورههاى تفسير مالايى

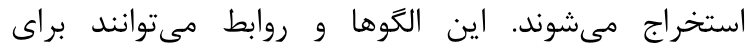

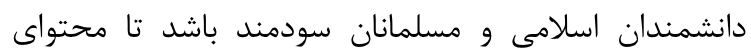
موضوعات قرآن در زندگَى و اعمال روزمرهشان تأثير كذار باشد.

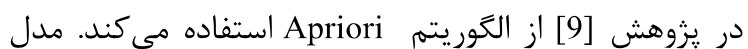
يافتن الكَوى مكرر از دو فرايند اصلى تشكيل شده است:

$$
\text { • • كشف الكَوى مكرر }
$$

مجموعهداده از سورههاى ترجمهشده به زبهاب زبان مالايى كه

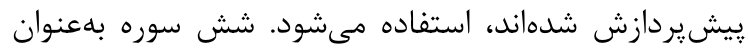

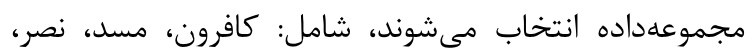

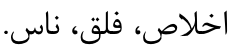

مرحله يِيشيردازش مجموعهداده شامل حذف كلمات توقف، نشانهها و نشانههاى نقطه مَذارى و بهعلاوه بركردانداندن متن به نمونه اوليه بهمنظور استانداردسازى است. در اين متن كلمات توقف، شامل كلماتى هستند كه اهميت كمترى دارند و شامل ضr كلمهٔ توقف است. در يزوهش [9] هر سوره از ترجمة مالايى قرآن بهعنوان

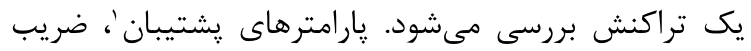

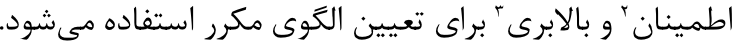

\footnotetext{
${ }^{1}$ Support

2 confidence

${ }^{3}$ lift
} 
مىشود و يا اجناس خريدارىشده از فروشگاههاى زنجيرهاى،

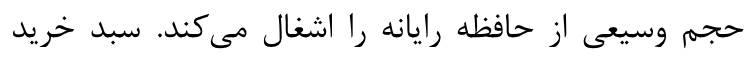

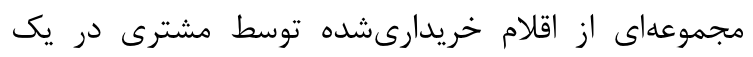

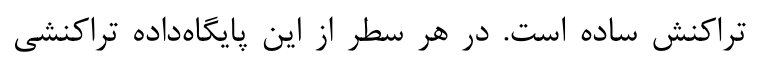

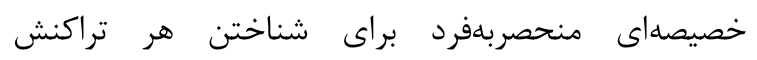

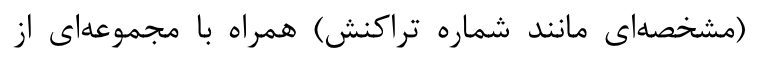

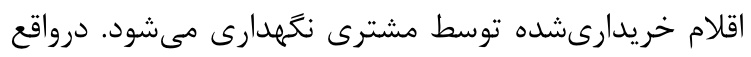

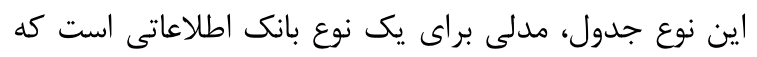

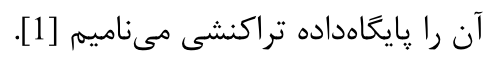

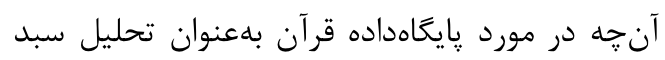

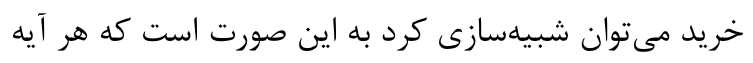

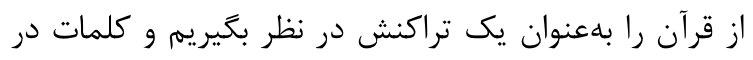

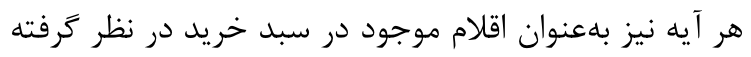

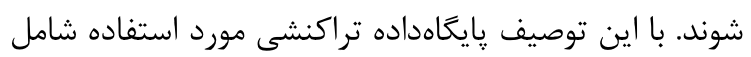

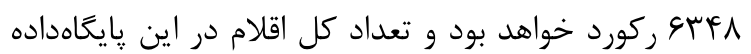

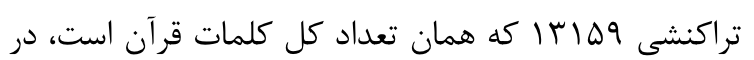
نظر كرفته شده است.

\section{r-r-r - بيش يردازش دادهها}

براى جمعآورى دادههاى كل قرآن با همكارى مركز تحقيق داديقات

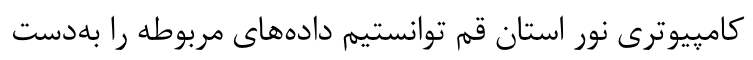

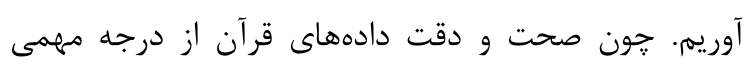

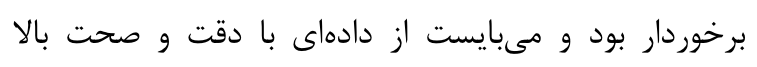

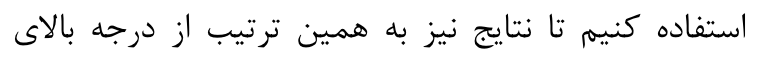
صحت و درستى برخوردار باشد.

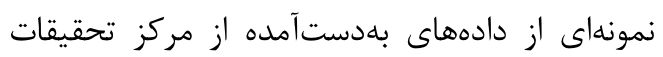

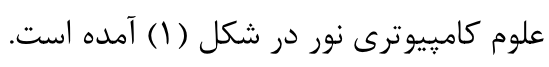

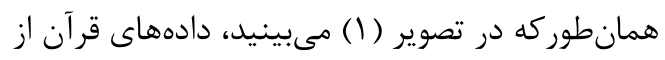

$$
\begin{aligned}
& \text { ستونهاى زير تشكيل شده است: } \\
& \text { 1. شمارة كلمه } \\
& \text { r. }
\end{aligned}
$$

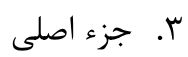

$$
\begin{aligned}
& \text { f. } \\
& \text { ه. ارمأ آيه }
\end{aligned}
$$

درباره شمار آيات قرآن، نظرهاى مختلفى ديده مىشود آندا

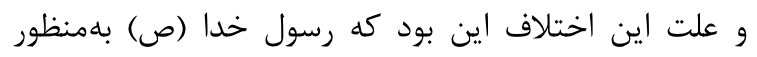

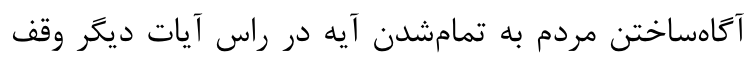

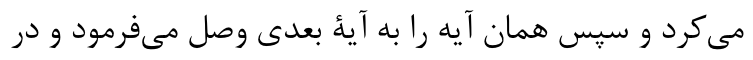



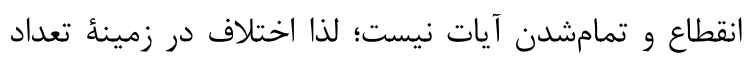

شامل زبان عربى نيز براى عموم مردم سودمند است. وجود

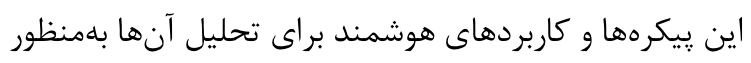

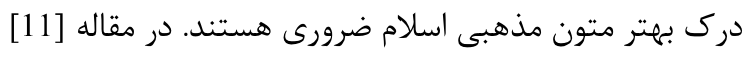

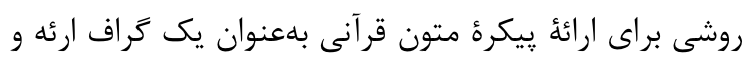

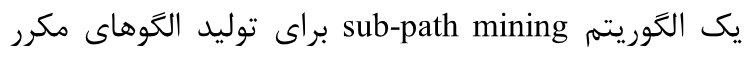

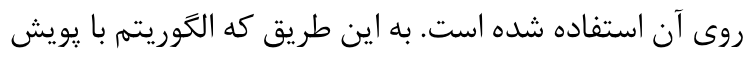

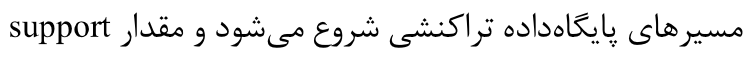

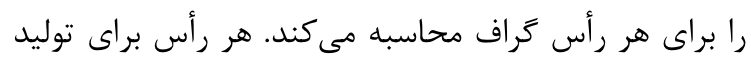

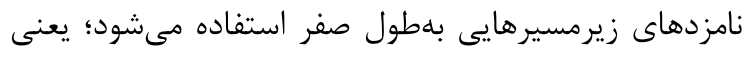

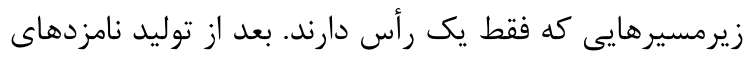

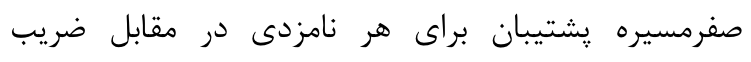

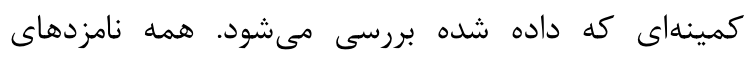

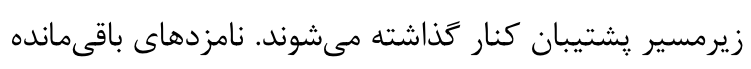

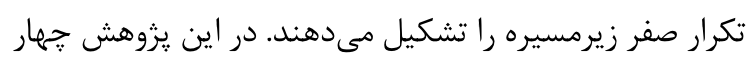

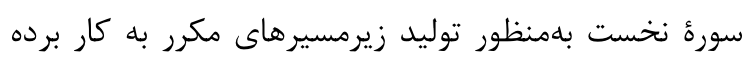
شده است.

\section{F-F - F - مرورى بر الكوريتمهاى كشف الگوى مكرر براى يافتن الكَوهاى مكرر انجمنى براى برى \\ جريان دادهها ترناي}

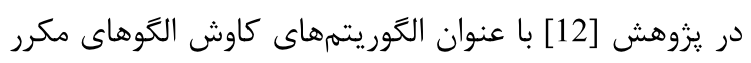

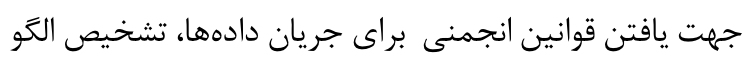

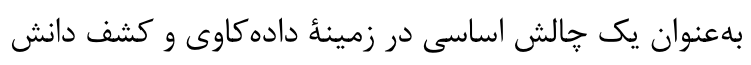

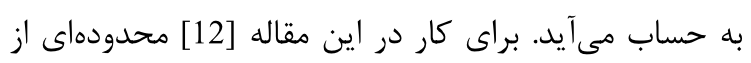

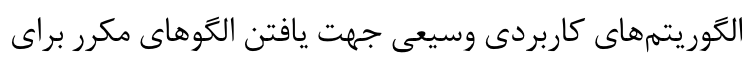

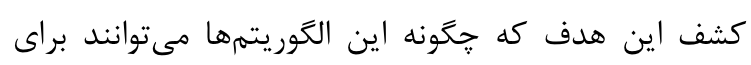

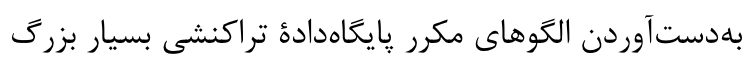

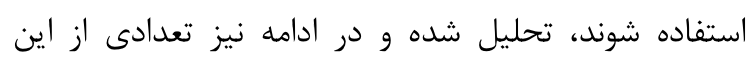

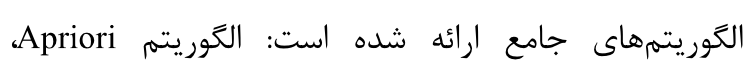

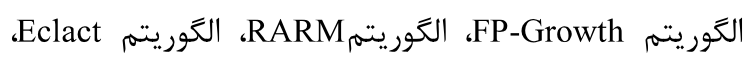

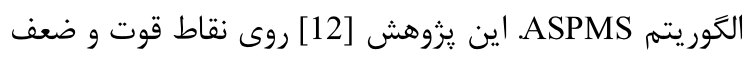

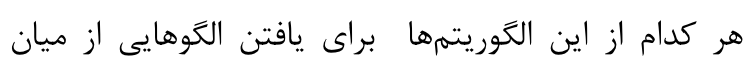

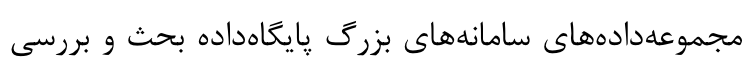

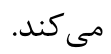

\section{r- روش انجام يزوهش

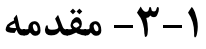

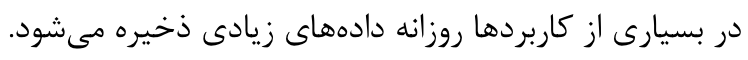
براى مثال در يك بانك روزانه تراكنشهاى ماري متعددى دادى انجام 
استفاده كنند، شايد اين مقادير ناقص در نتيجئ نهايى فرايند

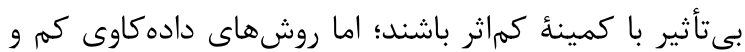

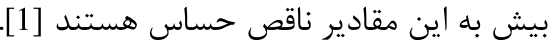

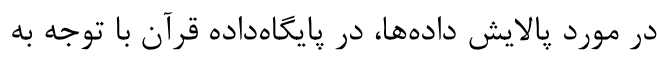
اينكه قرآن كتاب كامل و جامع از سوى فرستاده خداوند

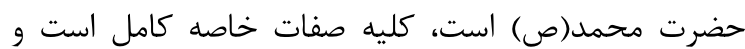
مقادير ناقص در اين يايخاهداده وجود ندارد.

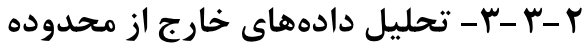

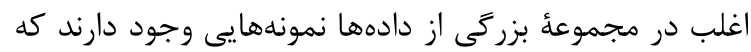

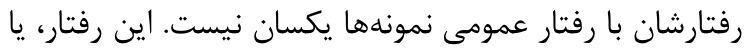
بهوروكامل مختلف است يا با ديخر نمونهها ناساز كارند.

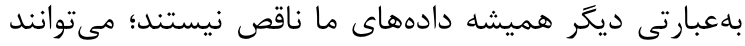

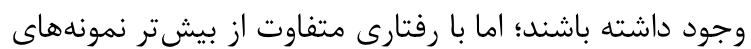
موجود، وجود اين نمونهها مىتواند دلايل متعددى مثل

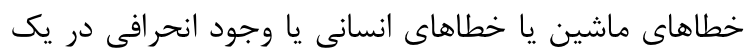

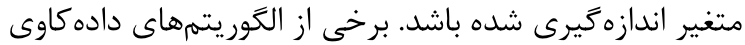

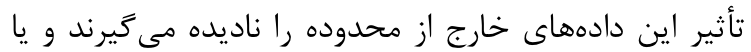

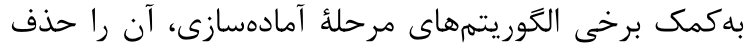

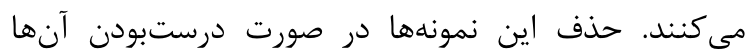

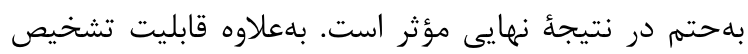

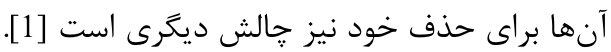
براى تحليل دادههاى خارج از محدوده در يايخاهداده

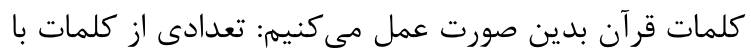

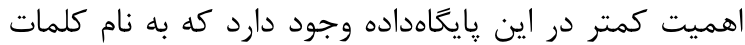

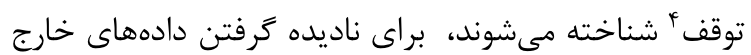

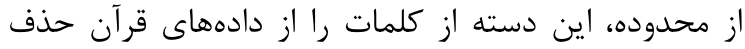

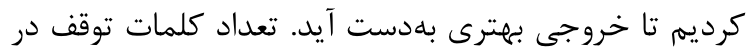

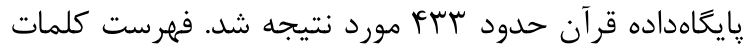
توقف در شكل (r) نشان داده شده است.

\begin{tabular}{|c|c|c|c|c|c|c|}
\hline INSERT & PAGE LAVO & & & |ATA & VIE & \\
\hline u & $T$ & $s$ & $R$ & Q & $P$ & 0 \\
\hline مينها & |متكن & لإن & | تَا & التكني & إنَّلَّى & قدذ \\
\hline مبنة & متعَكَّمَا & لبِّى & كنْ & لنجنئ & نتانت & كآيتئن \\
\hline مبنهيتا & مَغكَم & لكَّى & 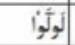 & لنكينّ & لدئتَا & كألثي \\
\hline مِنَهُمَ" & متنَّا & 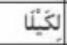 & لَوَلَّلَّتَ & لكَكَّا & لديّيَ & كألذّى \\
\hline 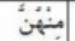 & معنة & إلبكُّ" & |تو & 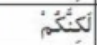 & لدئيه: & كأذذبن \\
\hline مُكَّا & 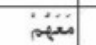 & الُلْتَى & لَوُورًا & كَكَُّْ & لدى & كأن \\
\hline لنكت & مَمعى & ألَذّى & |نها & تكنََِّْ & لنُوْ & كأَّك" \\
\hline , & أمتن & التلنَينئ & 4 & لكنَّى & تعلَّ & كأَّمَا \\
\hline هُ & |مَنَي & م. & لَهْهًَ & الثلّنى & لثئك' & كأنهاب \\
\hline
\end{tabular}

(شكل - (T): فهرستى از كلمات توقف در قر آن (Figure-2): A list of stop words in the Quran

${ }^{4}$ stop words
آيات باعث اختلاف نظر در شمار آنها شد. رسول خدا (ص) آنآ

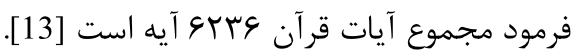

\begin{tabular}{|c|c|c|c|c|c|}
\hline آيه & (نوشتارى) & (اصلى) & كلمه & شلمه & رديف \\
\hline 1 & ب & ب & بِسْرِ & 1 & 1 \\
\hline 1 & سُمٍ & إِسنٌْ & بِسٍْْ & 1 & $r$ \\
\hline 1 & اللَه & اللَه & الله & $r$ & $r$ \\
\hline 1 & ال & الْ & الرَرَحْمَنِ & $r$ & f \\
\hline 1 & رَخْمَنِ & رَخْمَنِ & الرَّحَحْنِنِ & $r$ & $\Delta$ \\
\hline 1 & ال & الْ & الرَّجِيمِ & F & 9 \\
\hline 1 & رَرجِيمِ & زَحِيمِ & الرَّجِيمِ & F & v \\
\hline$r$ & الن & الن & الْحَمْنُ & $\Delta$ & $\Lambda$ \\
\hline$r$ & حَمْنَ & حَمْنُ & الْحَمْنُ & $\Delta$ & 9 \\
\hline$r$ & لِ & $ل$ & لـ & 4 & 1. \\
\hline$r$ & لَ & اللَّ & الثله & 9 & 11 \\
\hline$r$ & رَبَّ & رَبَّ & رَبّ & v & Ir \\
\hline$r$ & الن & الن & الَّاَاَلمِينَ & $\wedge$ & $\pi$ \\
\hline
\end{tabular}

(شكل -1): تصويرى از دادههاى قر آن كريم بركرفته از مركز تحقيقات علوم كامييوترى اسلامى نور

(Figure-1): A picture of the Qur'anic data from the Islamic Research Center of Computer Science, Nour.

\section{r-r- روشهاى آمادهسازى دادهها}

آمادهازى دادهها به مراحل قبل از دادهكاوى اطلاق مىشود؛

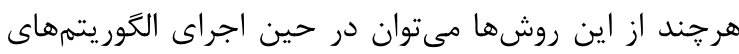

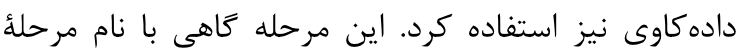

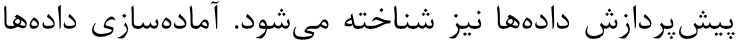

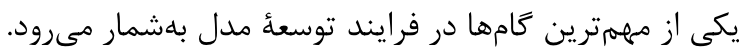
كيفيت دادههاى ورودى در سادهترين تحليل تا ساخت ساخت مدلهاى ييجيده يكى از كليدهاى موفقيت انجام يك يروزين

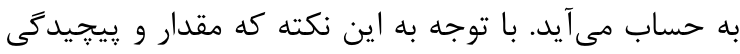

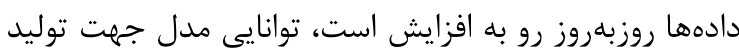

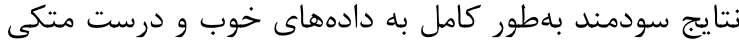

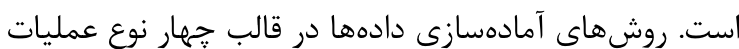

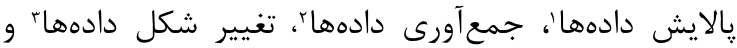

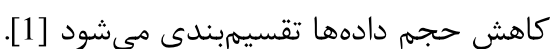

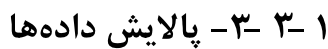
حتى در برنامههاى كاربردى واقعى با مقدارِ زيادِ دادهها، مىتوان نمونههايى را يافت كه مقدارى براى صناي صفات خاصدئ

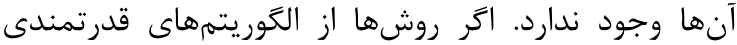

${ }^{1}$ Data cleaning

${ }^{2}$ Data integration

${ }^{3}$ Data transformation 
بسيار مهمم هست و همجنين بايد طورى ريشهيابى را در

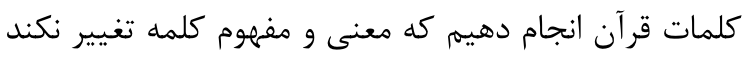

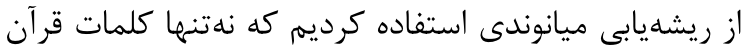
ريشهيابى شوند، بلكه معنى و مفهوم كلمه نيز تغيير نكند، النقان

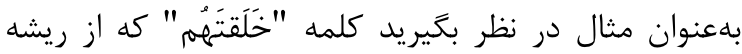

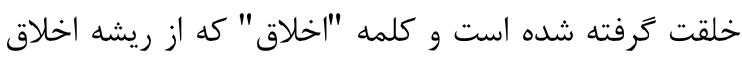

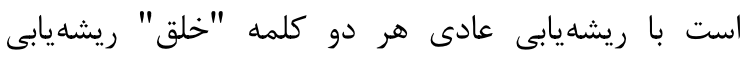
مىشود؛ درصورتى كه معنا و مفهوم بهطور كامل متفاوتى دارند؛

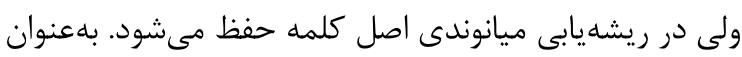

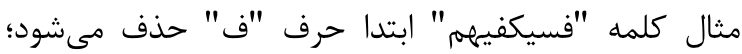

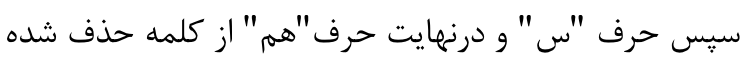

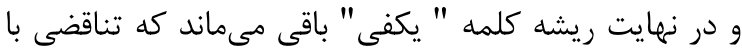

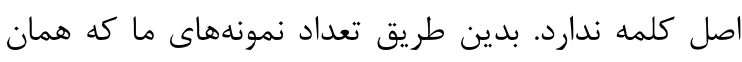

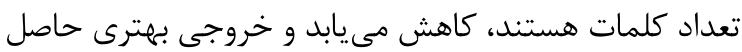

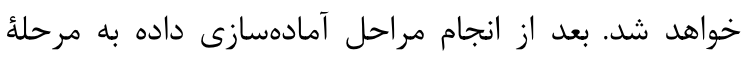
يافتن الكوهاى مكرر خواهيم رسيد.

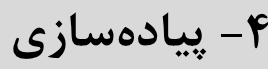

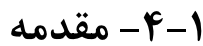

بعد از انجام مرحله پِالايش دادهها، در اين بخش پيادهادسازى و

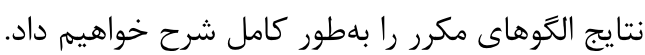

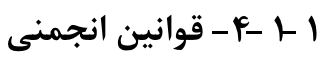

مى خواهيم وابستخىهاى مهام ميان اقلام موجود در يك

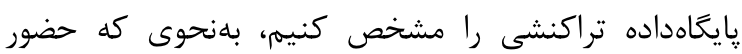

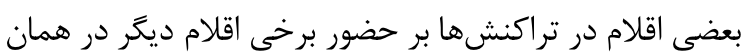

تراكنشها دلالت دارد [1]].

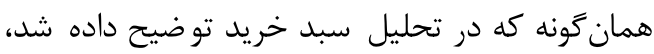

براى شـبيهسـازى (البته بدون همانندسـازى) آيات و كلمات

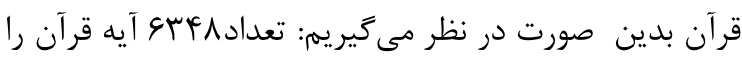

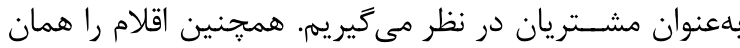

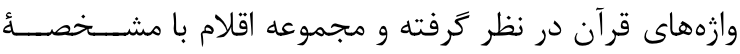

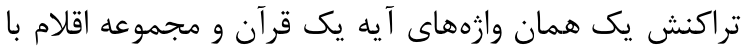

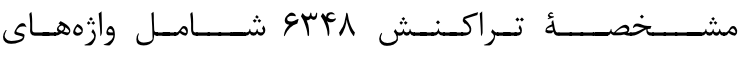
"من"،"ال"،"جنت"،"و"،"ال"،"ناس"خواهد بود. يك مشخصؤ مهم براى مجموعه اقلام، يشتيبان ناميده مىشود كه برابر است با تعداد تراكنشهايى كه شامل مجموعه براي

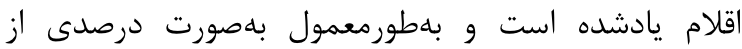
تراكنشها كه مجموعه اقلام را شامل مىشوند، بيان مىشود بأن

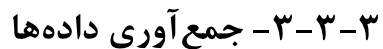

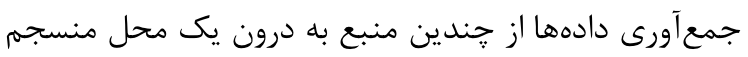

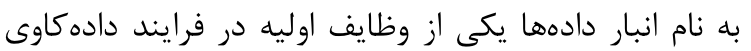

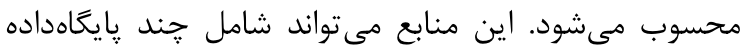

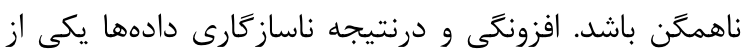

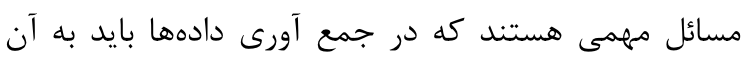

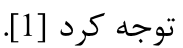
در بايحاهدادؤ قرآن نيازى به انجام اين مرحله نبود؛ زيرا

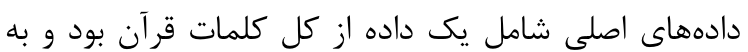

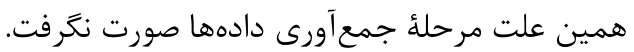

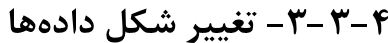

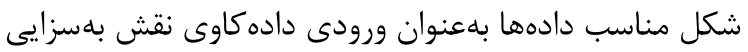

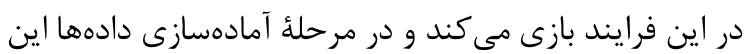

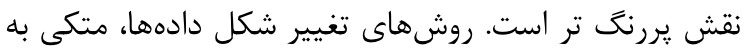

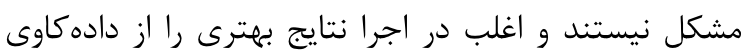
سبب مىشود [1]. در بايكاهداده قرآن براى تغيير شكل داده تنها تغييرى كه صورت كرفت، حذف اعراب از كلمات بود. با اين تغيير، كدنويسى و انجام مراحل بعدى بسيار سادهتر شد.

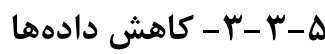

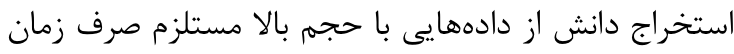

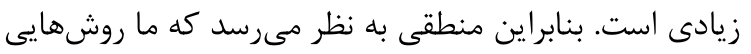

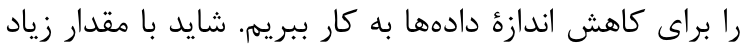

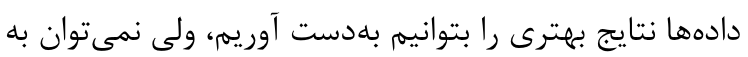

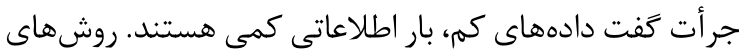

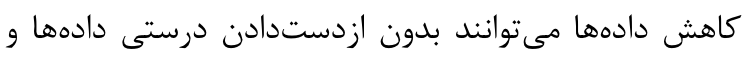

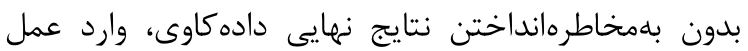

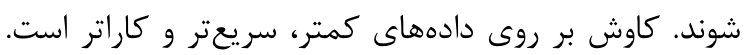

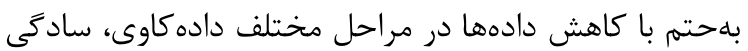

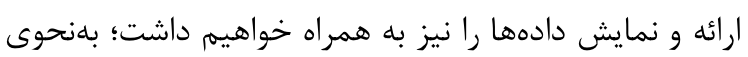
كه مدل، قابل فهمتر خواهد بود [1].

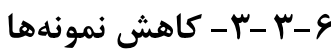

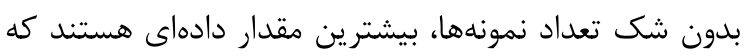

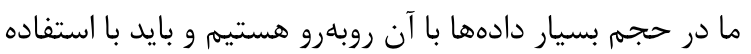

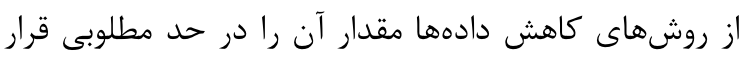

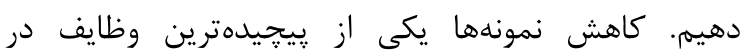

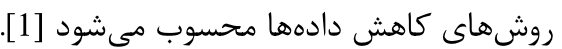

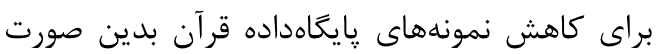

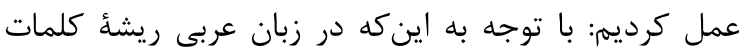


بعضى وازمها در تراكنشها بر حضور برخى وازمهاى ديكر در

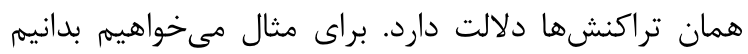

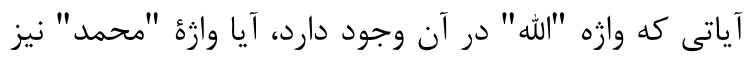

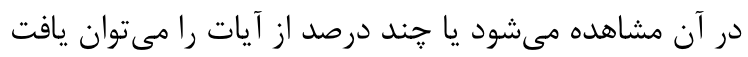

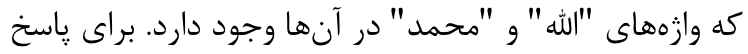

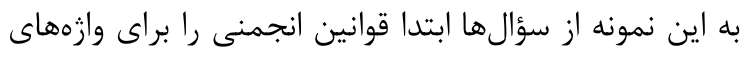

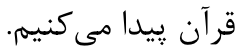

از ديدگاه كلى كاوش قوانين انجمنى را مىتوان يك بن فرايند دومرحلهاى در نظر كرفت: • • يافتن كلئ مجموعه اقلام مكرر

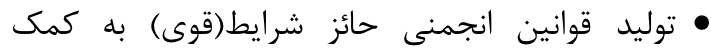
مجموعه اقلام مكرر بيداشده در مرحلئ قبل

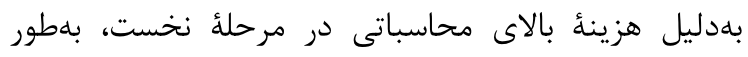

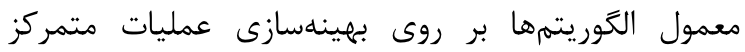

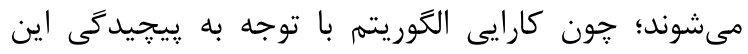
مرحله سنجيده مىشود [1].

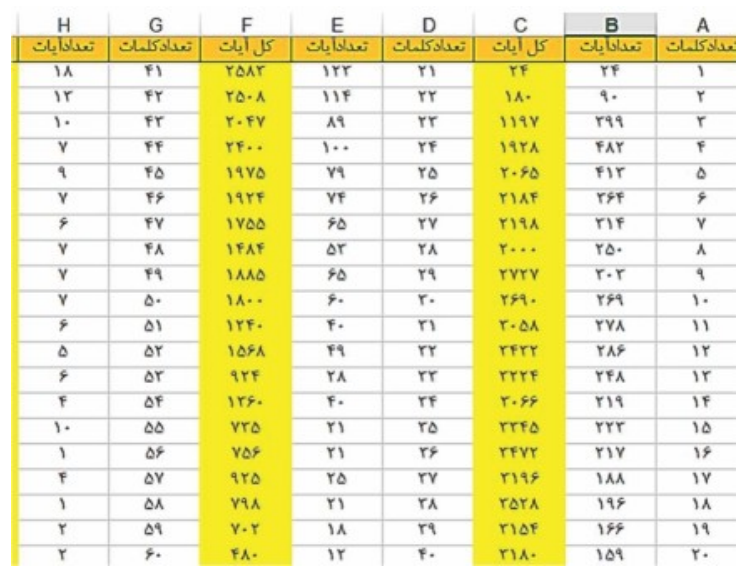

(شكل-r): تعداد كلمات با تعداد آيات يكسان

(Figure-3): Number of words with the same number of verses

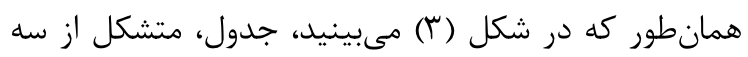

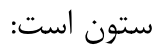
ستون دوم تعداد آياتى را نشان مىدهد كه در ستون نخست

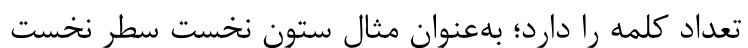

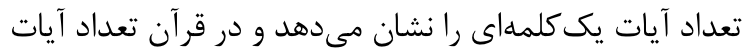

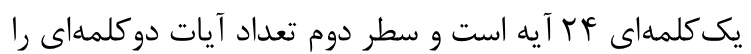
نشان مي دهد و به همين صورت تا آخر. درنهايت با محاسبه تعداد كلمات كه قrVVV

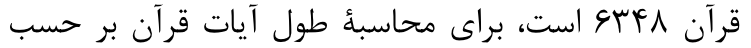

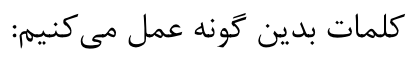

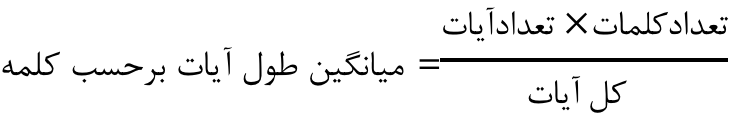

الكوريتمهاى كشف قوانين انجمنى، مستعد توليد تعداد بسيار زيادى از قوانين هستند. حتى با تعداد كم اقلام دادهها

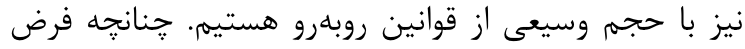

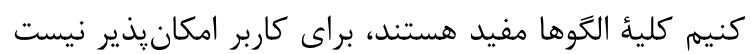
تا قضاوت مناسبى ميان آنها داشته باشد. بدين علت نياز به

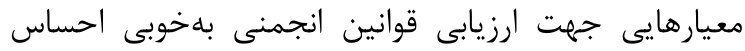

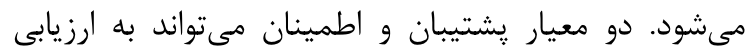

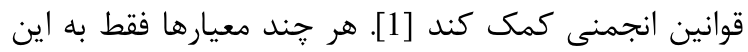

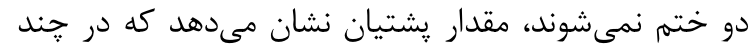
درصد از تراكنشهاى بايخاهدادهها مىتوان مجموعه اقلام

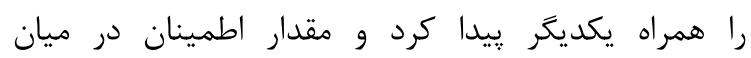
تراكنشهايى كه مجموعه اقلام X را در خود دارند، بهدنبال

Support $(\mathrm{X} » \mathrm{Y})=\mathrm{P}(\mathrm{X} \cap \mathrm{Y})$

مجموعه اقلام Y مىشود.

Confidence $(\mathrm{X}) \mathrm{Y})=\mathrm{P}(\mathrm{Y} \mid \mathrm{X})=\mathrm{P}(\mathrm{X} \cap \mathrm{Y}) 1 \mathrm{P}(\mathrm{X})$

يكى از معيارهاى ارزيابى همبستكى ساده Lift نام دارد كه

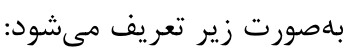

Lift=Confidence(A»B).Support(B)

معيار ديكرى كه جهت بررسى همبستَى استفاده مىشود، €-Coefficient نام دارد و بهصورت زير معرفى معىشود:

$€$-Coefficient $=-(\mathrm{P}(\mathrm{A} \cap \mathrm{B})-\mathrm{P}(\mathrm{A}) \cdot \mathrm{P}(\mathrm{B}) \cdot \sqrt{ }$

$\mathrm{P}(\mathrm{A}) \cdot \mathrm{P}(\mathrm{B}) \cdot \mathrm{P}(1-\mathrm{P}(\mathrm{A})) \cdot(1-\mathrm{P}(\mathrm{B}))$

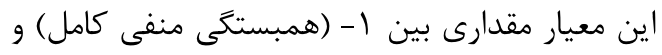

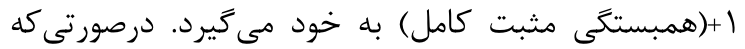

a,b مستقل باشند، مقدار آن برابر با صفر خواهد بود بود [1].

\section{r}

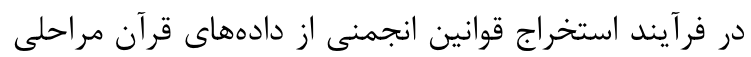

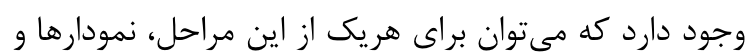

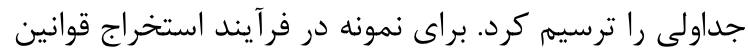

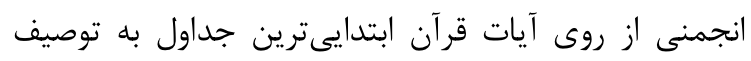

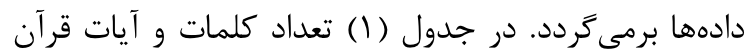

بهترتيب بهعنوان اقلام و مجموعهها در نظركر فرته شدهاند.

(جدول-(): تعداد آيات و وازهها در قرآن

(Table-1): Number of verses and words in the Quran

\begin{tabular}{|c|c|c|c|}
\hline تعداد & معادل در يُووهش ما & عنوان & شماره \\
\hline GH4 & آيات & مجموعهها & 1 \\
\hline 15109 & كلمات & اقلام & $r$ \\
\hline
\end{tabular}

مىخواهيم وابستگى هاى مهم ميان وازمهاى موجود در اين يايخاهداده تراكنشى را مشخص كنيم؛ بهنحوى كه حضور 
Support $=1.6348=0.00015753$

محاسبة ضريب يشتيبان هT UT كلمؤ موجود فقط در دو آيه: Support $=2.6348=0.00031506$

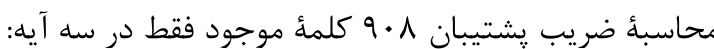

Support $=3.6348=0.00047259$

در جدول (r) مقدار ضريب يشتيبان براى بيست رديف جدول

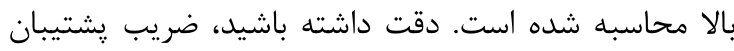

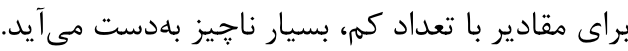

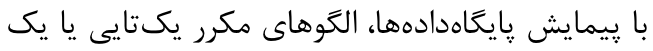

$$
\text { عضوى بلهدست مى آيند. }
$$

(جدول-r): جدول محاسبه ضريب پِشتيبان براى آيات با تعداد

$$
\text { كلمه يكسان }
$$

\begin{tabular}{|c|c|c|c|c|c|}
\hline 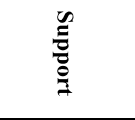 & $\begin{array}{l}\hat{\xi} \\
\frac{\varepsilon}{\xi} \\
\xi\end{array}$ & $\underline{\varepsilon}$ & 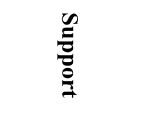 & $\begin{array}{l}\frac{\xi}{\xi} \\
\frac{c}{\xi} \\
\varepsilon_{:}\end{array}$ & $: \underline{\varepsilon}$ \\
\hline 0.001732829 & 69 & 11 & 0.00015753 & 7586 & 1 \\
\hline 0.001890359 & 69 & 12 & 0.00031506 & 2152 & 2 \\
\hline 0.002047889 & 63 & 13 & 0.00047259 & 908 & 3 \\
\hline 0.002205419 & 46 & 14 & 0.00063012 & 581 & 4 \\
\hline 0.002362949 & 37 & 15 & 0.00078765 & 366 & 5 \\
\hline 0.002520479 & 37 & 16 & 0.00094518 & 261 & 6 \\
\hline 0.002678009 & 29 & 17 & 0.00110271 & 192 & 7 \\
\hline 0.002835539 & 13 & 18 & 0.001260239 & 123 & 8 \\
\hline 0.002993069 & 19 & 19 & 0.001417769 & 109 & 9 \\
\hline 0.003150599 & 26 & 20 & 0.001575299 & 88 & 10 \\
\hline
\end{tabular}

(Table-2): The calculation of the backup coefficient for verses

در مرحسلة دوم بهكمكى اين مجمو عه اقلام مكرر و

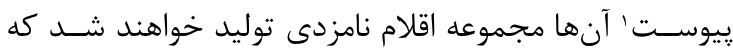

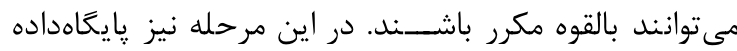

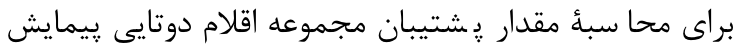
مىشـــود. يس از حذف مجمو عه اقلام دو تايى كه مـ مقدار

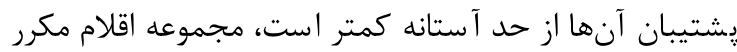

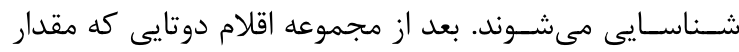

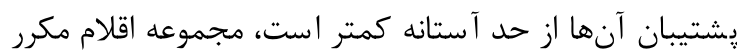

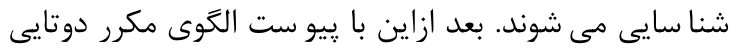

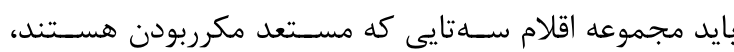

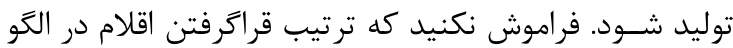

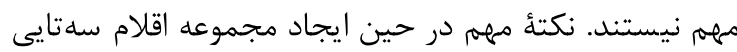

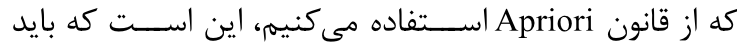
مجموعهاقلامى توليد شود كه تمام زيرمجموعههاى آن مكرر هسـتند. شـكل (ل) زيرمجموعه اقلام دوتايى يا جفت كلمات

$$
\text { يرتكرار را نشان مىدهد. }
$$

با محاسبه اعداد در فرمول بالا ميانغين طول آيات برحسب

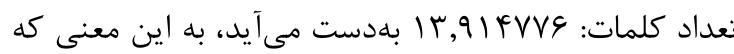
در هر آيه بهطور ميانكين حدود جهارده كلمه قرار دارد. شكل

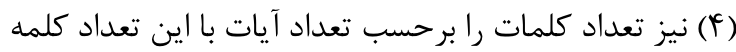

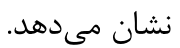

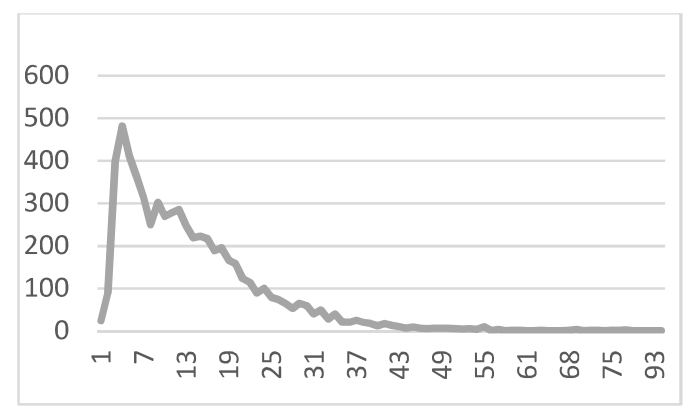

(شكل - (F): تصوير الكوهاى مكرر يكتايى يا يكعضـوى

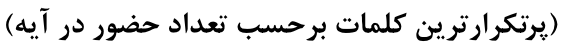

(figure-4): Frequent patterns of a single or a single member (most repetitive words based on the number of verses)

همانطور كه در شكل (F) مىبينيد تعداد آيات

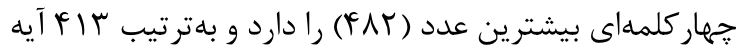

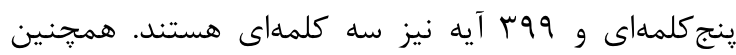


مىشود و كوجكترين آيه نيز يك كلمهاى است كه آنه

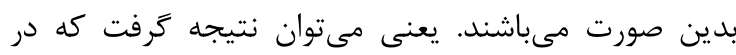

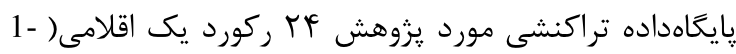
هستند و بزركترين ركورد itemset هitemsets براى يافتن الگوهاى مكرر در قرآن طبق الگوريتم Apriori آيات) و وهابا قلم داده (تعداد كلمات) الكوهاى مكرر يكتايى يا يكعضوى را بهدست مى آوريم. براى محاسبئ

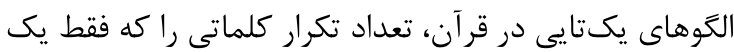

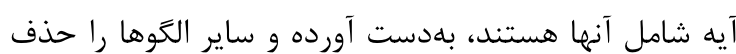

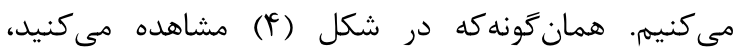



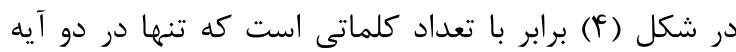

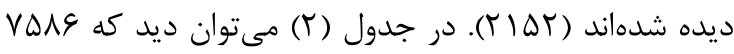
كلمه متفاوت در قرآن وجود دارد كه فقط يك آيه آيه شامل آنهاست (در يك آيه ظاهر شدهاند.) كه آشكار است اين تعداد فرداد كلمه از تعداد وهاس إ كلمه داراى ضريب ريشتيبان بسيار

$$
\text { يايينى خواهد بود. }
$$

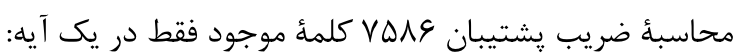


يرتكرارترين الكوى يكتايى، دوتايى و سهتايى كلمات طبق جدول (\&) استخراج شده است.

در ادامه فهرست قوانين حاصل مرحله استخراج

جندتايىهاى يرتكرار نشان داده شده است. لازم به ذكر است است كه ده قانون برتر در هر فهرست نشان داده شاد شده است. جدول (b) فهرستى از برترين قوانين يك فلماندان برحسب ضريب اطمينان يك نمايش داده شده است.

(جدول-1) : برتكرارترين الكَوى يكتايى، دوتايى و سهتايى كلمات قرآن

(Table-4): The most frequent single, double, and triple

\begin{tabular}{|c|c|c|c|c|c|c|}
\hline \multicolumn{7}{|c|}{ Quranic } \\
\hline$\frac{\iota}{\xi}$ & $\frac{G}{\frac{G}{\xi}}$ & $\frac{c}{\xi}$ & $\underset{\substack{G \\
\text { है }}}{G}$ & $\frac{c}{\xi_{i}}$ & $\begin{array}{l}\frac{G}{G} \\
\frac{G}{G} \\
C \\
C\end{array}$ & 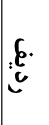 \\
\hline 110 & الله لرحيم/اسم & iva & الله/الأرض & iwre & الله & 1 \\
\hline 114 & الله /رحيم/رحمن & 189 & الله/قل & rTD & رب & r \\
\hline $11 f$ & الله رحمن/اسم & 199 & اللهارب & rAs & الأرض & r \\
\hline 114 & رحيم/رحمن/اسم & lar & الله/آمن & rv. & قال & r \\
\hline १. & الله/الأرض/سماوات & $14 \lambda$ & الأرض/سماوات & $r \Delta \Lambda$ & ق قل & $\Delta$ \\
\hline q. & آمن /عمل/صالحات & $14 \lambda$ & اللهارحيم & $r \cdot f$ & آمن & 9 \\
\hline$\Delta V$ & الأرض/سماوات/خلق & lfr & اللهارسول & rqF & قوم & v \\
\hline $\mathrm{v}$. & الله / حيم/غفور & If. & الشه/اسم & र१। & آيات & $\wedge$ \\
\hline 99 & الله/آخرة/دنيا & ira & الله/ناس & rAT & عذاب & 9 \\
\hline$\Delta 1$ & جنات/تجرى|ال & Tr & الله/يعلم & TAY & كن & 1. \\
\hline $\mathrm{Fr}$ & الله/عزيز/حكيم & 111 & الله/قال & rQV & كان & 11 \\
\hline
\end{tabular}

(جدول -ه): برترين قوانين يك كلمهاى برحسب ضريب اطمينان

(Table-5): Top rules of a word in terms of reliability

\begin{tabular}{|c|c|c|c|}
\hline Confidence & Support & then_part & if_part \\
\hline 1 & 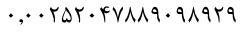 & آيات & تتلى \\
\hline 1 & $\cdot, \cdot r \Delta T \cdot F V A \Lambda q \cdot q \wedge Q T q$ & الله & حكيما \\
\hline 1 & $\cdot, \cdot$ rTGKqFAqG.r.rFG & الله & 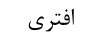 \\
\hline 1 & $\cdot, \cdot r Y \cdot \Delta F|q \cdot r q G| \Delta G Y$ & كان & يستهزؤن \\
\hline 1 & $\cdot, \cdot$.Y.DFIQ.TQGIDGK & يحيى & يميت \\
\hline 1 & $\cdot, \cdot r r \cdot \Delta F|q \cdot r q G| \Delta G Y$ & جن & الإنس \\
\hline 1 & $\cdot, \cdot r \cdot q \vee \wedge \Lambda q \cdot q \Lambda q \curlyvee \wedge \Lambda$ & غيب & عالم \\
\hline 1 & 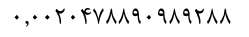 & الله & يضل \\
\hline 1 & $\cdot, \cdot$ IVTTATGTTVQDQIF & جنات & عدن \\
\hline 1 & 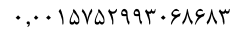 & الله & احق \\
\hline
\end{tabular}

برترين قوانين دوكلمهاى بر حسب ضريب اطمينان در جدول(9) نشان داده شده است.

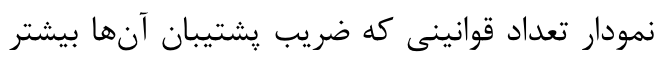
از ع/• است، در شكل (8) نشان داده شده است.

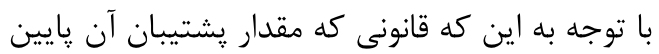

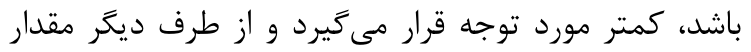

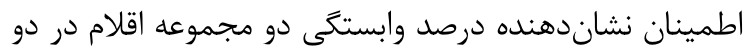

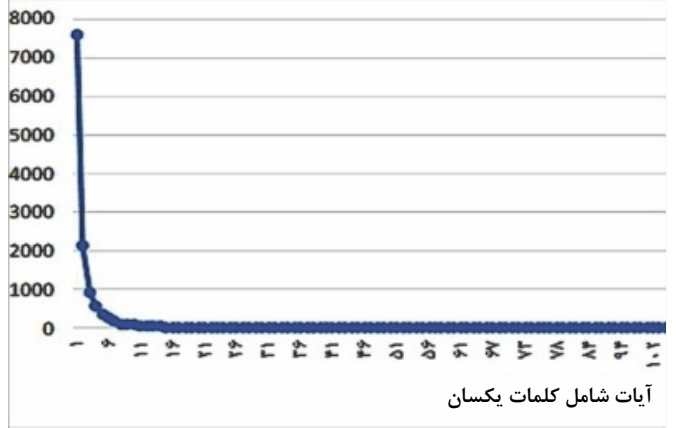

(شكل-ه): تصوير آمارى آيات با تعداد دوتايى كلمات يكسان (Figure-5): Statistical image of the verses with the same double number of words

در شكل (ه) نخستين نقطه، برابر با جفت كلماتى است

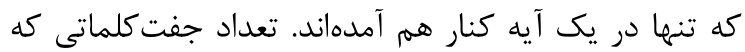

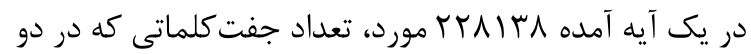
آيه آمده هأ ا • T مورد و تعداد جفت كلماتى كه در سه آيه آمده س أيه امده مورد بهدست آمده مورد است تعداد جعت

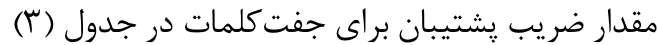

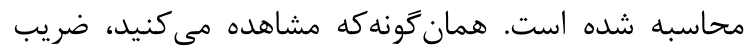

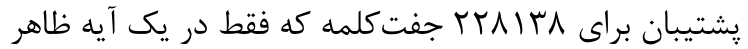

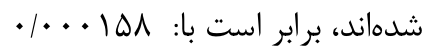

(جدول - Y): محاسبه ضريب يشتيبان براى جفت كلمات با تعداد آيات يكسان

(Table-3): Calculate the backup factor for pairs of words with the same number of verses

\begin{tabular}{|c|c|c|}
\hline Support & جفت كلمات & آيه \\
\hline 0.000158 & 228138 & 1 \\
\hline 0.000315 & 20145 & $r$ \\
\hline 0.000473 & 5643 & $r$ \\
\hline 0.00063 & 2384 & r \\
\hline 0.000788 & 1231 & $\Delta$ \\
\hline 0.000945 & 780 & 4 \\
\hline 0.001103 & 538 & $v$ \\
\hline 0.00126 & 347 & $\wedge$ \\
\hline 0.001418 & 283 & 9 \\
\hline 0.001575 & 179 & 1. \\
\hline 0.001733 & 149 & 11 \\
\hline 0.00189 & 104 & IT \\
\hline 0.002048 & 83 & ir \\
\hline 0.002205 & 78 & 14 \\
\hline 0.002363 & 52 & 10 \\
\hline
\end{tabular}

آمارهاى متعلق به مرحله استخراج الكوهاى يرتكرار بلوسيله الكوريته Apriori در اين يزوهش بلهصورت زير استخراج شده است:

تعداد كل يكتايىها با تكرار دستِكم ينج: .199 مورد تعداد كل دوتايىها با تكرار دست كم جهار: تعداد كل سهتايىها با تكرار دست كم سه: 


\section{ه- بحث و نتيجه}

اين يزوهش تلاشى براى بيادهسازى الكوهاى مكرر در قرآن با

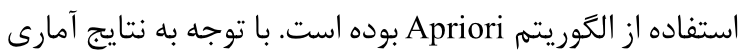
و ارزيابى آنها كه در اين يزوهش بهدست آمده است، مىتوان

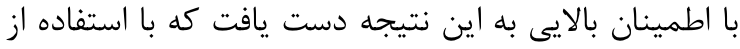

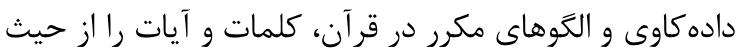
معنى، مفهوم و تفسير بيشتر مورد بررسى قرار داد تا بتوانيم

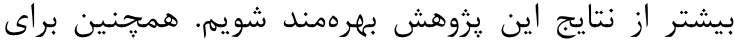

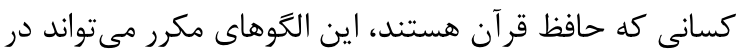
رسيدن به هدف عالى حفظ قرآن كمككننده باشد. براى كسانى كه بهدنبال اعجاز لفظى و عددى و معنايى در قرآن و يزوهش

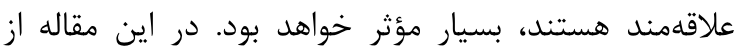
روشهاى متنكاوى جهت يافتن الكَوهاى مكرر در قرآن

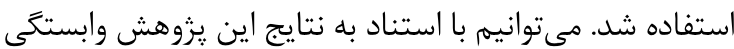

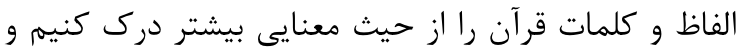
يافتن وازههايى كه در كنار يكديكر ظاهر شده و از نظر مفهوم و معنا مرتبط يا غير مرتبط هستند، تحليل و بررسى شود.

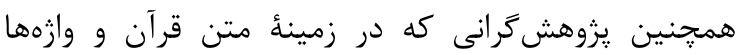

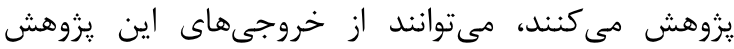
استفاده كنند و ارتباط و تعداد تكرار كلمات را در قرآن با توجه

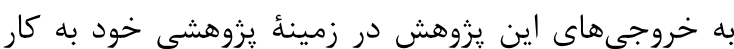
كيرند. •با بررسى هاى بهعمل آمده و جستجو در منابع كتابخانهاى و نشريات تخصصى مرتبط با رايانه مشخص شده فعاليتى در

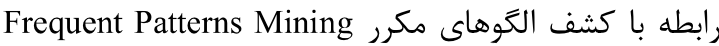
در قرآن در دانشكاه ساراواى كشور مالزى انجام شده است [9]. اين يزوهش بر روى شش سوره قرآن شامل" سوره

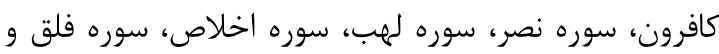

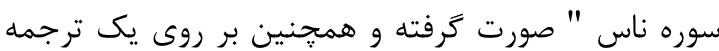
مالايى (زبان رسمى كشور مالزى) از قرآن انجام شده است؛

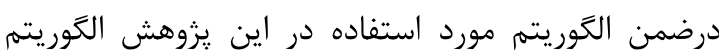
Apriori

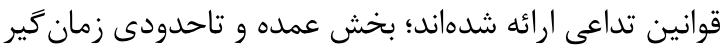

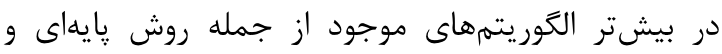
معروف Apriori جستجوى اقلام يرتكرار است [14]. •در اين يزوهش هدف بر اين است كه با استفاده از الكَوريتمهاى متن كاوى الكَوهاى مكرر در قرآن جستجو و وآين

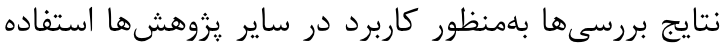

طرف قانون انجمنى است، شكل (9) تعداد قوانينى را نشان

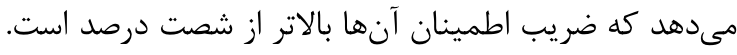

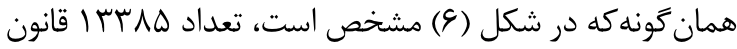

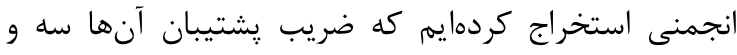
ضريب اطمينان آن بالاتر از ع| • است.

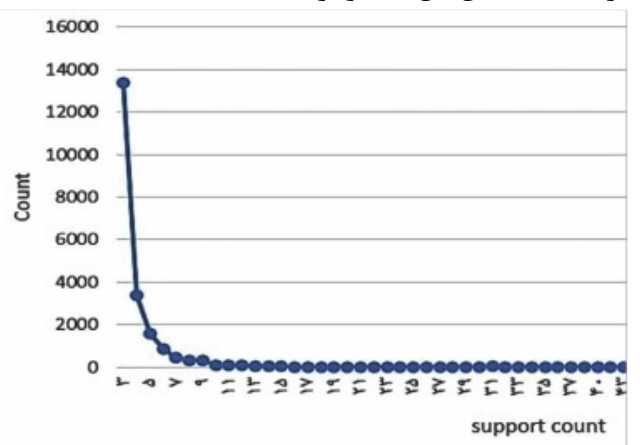

(شكل-9): تصوير تعداد قوانينى كه ضريب اطمينان آنها بيشتر از و/ • است.

(Figure-6): Image number of rules with a confidence rating of more than 0.6.

(جدول-9): برترين قوانين دوكلمهاى بر حسب ضريب اطمينان

(Table-6): Top two-word rules in terms of reliability

\begin{tabular}{|c|c|c|c|}
\hline 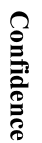 & 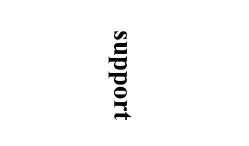 & 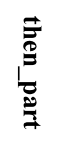 & 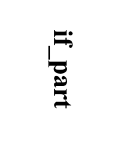 \\
\hline 1 & $\cdot, \cdot \backslash \wedge \| 1 \Delta q \& Y \cdot r \wedge q \wedge \Delta \Delta$ & الله & رحيم/اسم \\
\hline 1 & 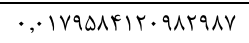 & الله & رحمن/سم \\
\hline 1 & 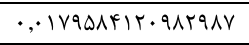 & رحيم & رحمن/اسم \\
\hline 1 & $\cdot, \cdot \cdot \Lambda \cdot r K \cdot r G 49 \Delta \cdot$. TAYG & عمل & آمن /صالحات \\
\hline 1 & $\cdot, \cdot$ DI QAFAVVIYGGQAFI & تجرى & جنات/الأنهار \\
\hline 1 & $\cdot, \cdot \Delta|q \Lambda F A V V I T G G \Delta F|$ & الأنهار & جنات/تجرى \\
\hline 1 & $\cdot, \cdot$ FMATFYVADITQIVA & رب & تكذب/آلاء \\
\hline 1 & $\cdot, \cdot$ FMATFFVADITQIVD & آلاء & رب/تكذب \\
\hline 1 & 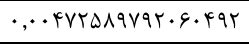 & الأرض & شىء/سماوات \\
\hline 1 & $\cdot, \cdot R F I \cdot \Delta r \wedge \cdot \Delta q r r \mid r \Delta$ & عذاب & الله/اليم \\
\hline
\end{tabular}

برترين قوانين انجمنى برحسب ضريب همبستخى در جدول

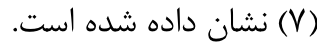

(جدول): بر ترين قوانين انجمنى برحسب ضريب همبستكى

(Table-7): Top association rules in terms of correlation coefficient

\begin{tabular}{|c|c|c|c|}
\hline 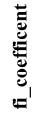 & 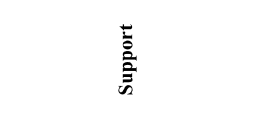 & 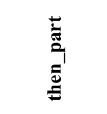 & 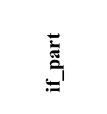 \\
\hline 1 & $\cdot, \cdot \cdot 11 \cdot r V \cdot q \Delta \mid f \lambda \cdot V A 1$ & ستهٔ & سماوات/ايام \\
\hline 1 & $\cdot, \cdot \cdot 1|\cdot r V \cdot q \Delta| F \wedge \cdot V \Lambda \mid$ & سماوات/ايام & ستؤ \\
\hline 1 & $\cdot, \cdot \cdot 11 \cdot r \gamma \cdot q \Delta|f \wedge \cdot V \Lambda|$ & ستؤ & الأرض/يام \\
\hline 1 & $\cdot, \cdot \cdot|1 \cdot r \gamma \cdot q \Delta| f \Lambda \cdot V \Lambda \mid$ & الأرض/يام & سته \\
\hline 1 & $\cdot, \cdot \cdot|1 \cdot r V \cdot q \Delta| f \wedge \cdot V A \mid$ & سته & خلق/ايام \\
\hline 1 & $\cdot, \cdot \cdot|1 \cdot r V \cdot q \Delta| f \wedge \cdot V \lambda \mid$ & خلق/ايام & 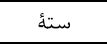 \\
\hline 1 & $\cdot, \cdots q q \Delta I V q \Delta \Delta \uparrow \mid r \cdot q \Lambda \mu$ & قهار & الله/واحد \\
\hline
\end{tabular}


مىشود، دستهبندى مناسبى قبل از انجام مرحله جستجوى الخوهاى مكرر صورت گيرد تا خروجى قابليت تفسير و تحليل بهترى يابد. r. انجام خوشهبندى مناسب از سورهها يا كلمات بعد از يافتن الگوهاى مكرر: ييشنهاد مىشود خروجى بلهدستآمده از مناز يزوهش، خوشهبندى شده تا نتايج از حيث تعداد خوشه و مفهوم قابليت تحليل بهترى داشته باشد. f. انجام دستهبندى مناسب از سورهها يا كلمات بعد از يافتن الكوهاى مكرر: ييشنهاد مىشود مانند بند سه خروجى بهدستآمده از يروهش، دستهبندى شده تا نتايج از حيث تعداد خوشه و مفهوم قابليت تحليل بهترى داشته باشد. ه. در يروهش يادشده، مرحلهاى بهعنوان وزندهى به به وازمها استفاده نشده است؛ بدين صورت كه مىتوانستيم براى هر وازه در يك آيه يك وزن و در صورت تكرار وازه در همان آيه دو وزن براى وازه مذكور در نظر بخيريم تا نتايج بهتر و دقيقترى استخراج كنيم. براى بهبود خروجى ييشنهاد

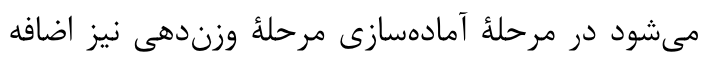

\section{7- References}

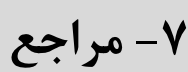

[1] اسماعيلى، مهدى، مفاهيمر و تكنيكهاى دادهكاوى،

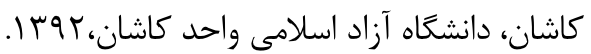

[1] M. Esmaieli, Concepts and techniques of data mining ,Kashan;Azad University of Kashan,2013. [ץ] رادفر،رضا، نظافتى، نويد، يوسفى اصلى، سعيد، "طبقه

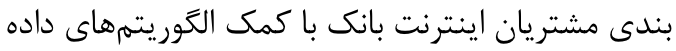

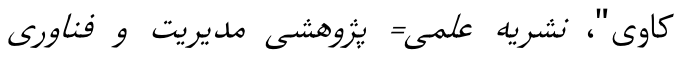

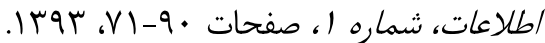

[2] R. N. Y. Radfar.R, Nezafti.N, Yoosefi Asli.S. Classification of Bank Internet Customers Using Data Mining Algorithms. IT management, pp7190, 2014.

[ب] آقاكاردان، احمد، كيهانى نزاد، مينا،" ارائه مدلى براى استخراج اطلاعات ازمستندات متنى مبتنى بر متن كاوى

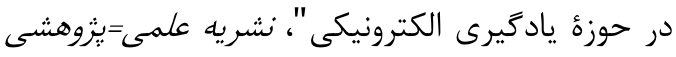

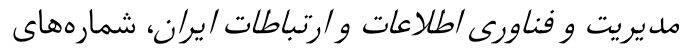

$$
\text { || اورال،صفحات }
$$

[3] A. M. Aghakardan, Keihani Nejad. Provides a model for extracting information from textual texts based on e-learning, IT management,pp 47-54,2012.
شود. دو تفاوت اساسى كه با ساير يزوهشها [9] دارد بهشرح زير است: • يزوهش يادشده مبتنى بر روى مجموعهدادهاى از كل قرآن

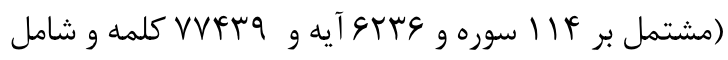

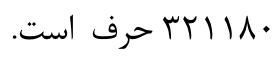

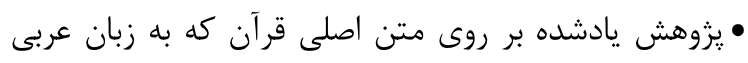

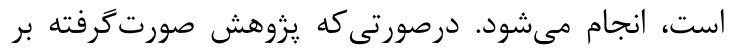
روى ترجمة خاصى از قرآن و به يك زبان خاصى انجام شده

است [9].

\section{9- و بيشنهادها}

نكته قابل توجه در اينجا اين است كه نتايج بهدستآمده از

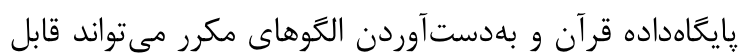
تسرى به ساير كتابهاى آسمانى ديخر نيز مىباشد، زيرا

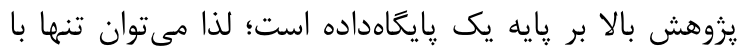

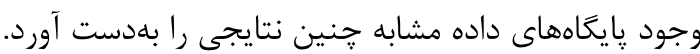

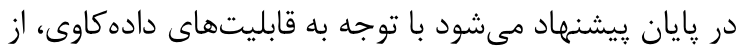
منابعى مانند نهج البلاغه، صحيفه سجاديه و همرجنين كتب



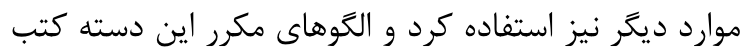
نيز بررسى و درنهايت ارتباط يا تلفيقى از خروجىها با هم

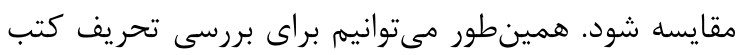

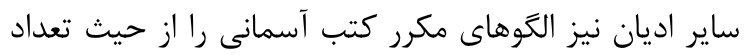
كلمات و جفت كلمات و تكرار وازمها مقايسه و علل تحريف اين كتب را بررسى كنيه.

بهعنوان كارهاى يزوهشى آينده كه مىتوانند در جهرت

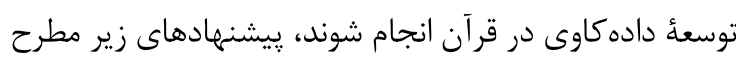

مىشود: I انجام خوشهبندى مناسب از سورهها يا كلمات قرآن قبل از

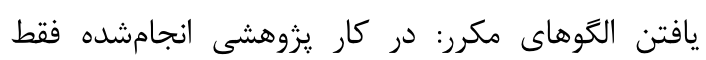
مرحله ريشهيابى و حذف كلمات توقف براى مرحلة

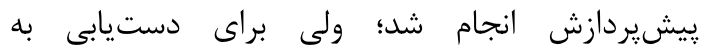
خروجىهاى دقيقتر و دستهبندىشده پيشنههاد مىشود تعداد سورهها يا كلمات قرآن را ابتدا خوشهبندى و بعد از انجام ارزيابى خوشهبندى و يافتن تعداد خوشأ مناسب الكوهاى مكرر را در قالب هر خوشه جستجو و درنهايت به خروجى جهت يابى شدهترى دست ييدا كنيم.

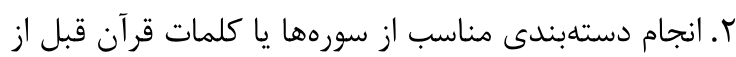
يافتن الكوهاى مكرر: همانند توضيحات بند قبلى، ييشنهاد 


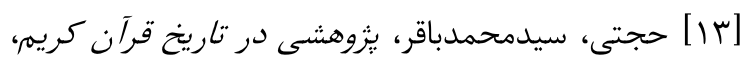

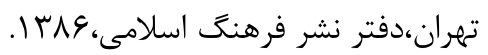

[13] H. Hojati, Research in the history of the Holy Qur'an, Teh-ran: Publishing House of Islamic Culture, 2006.

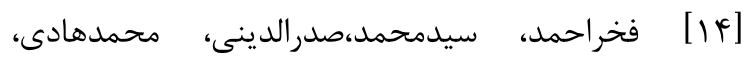

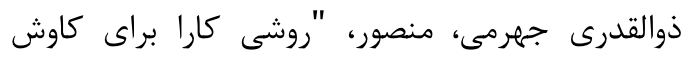

مجموعه اقلام يرتكرار در تحليل دادههاى سبد خريد"، درئ

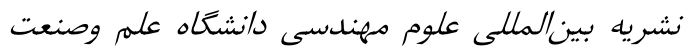

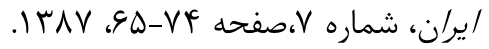

[14] F. Z. Fakhr Ahmad, Zolghadri Jahrom, An Effective Method for Exploring Over-theCounter Items in Cart Basket Analysis. The International Scientific Engineering Department of Iran University of Science and Technology, pp 65-75, 2009.

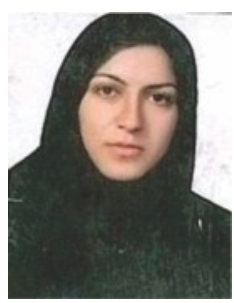

اكرم اصلانى، مدرى كارشناسى خود را

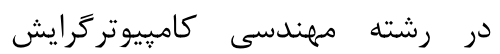
نرم|فزار در سال rی از دانشكاه پيام نور

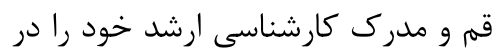

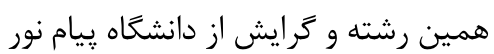

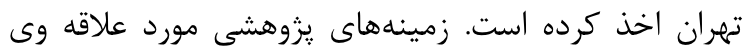

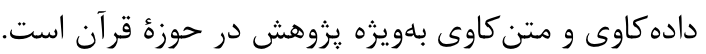

\section{Pnuakaslani@yahoo.com}

$$
\text { نشانى رايانامٔ ايشان عبارت است ازئ }
$$

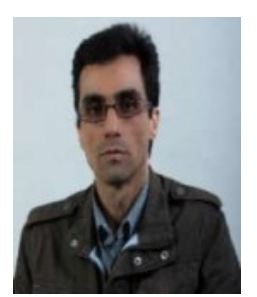

$$
\begin{aligned}
& \text { مههدى اسماعيلى مدرك كارشناسى } \\
& \text { خود را در رشته كامبيوتر كرايش نرم- } \\
& \text { افزار در سال سكسا از دانشكاه اصفهان }
\end{aligned}
$$

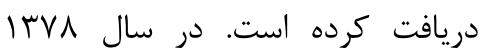

$$
\begin{aligned}
& \text { كارشناسى ارشد خود را درهمين رشته }
\end{aligned}
$$

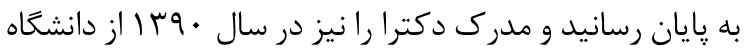
دبرسن مجارستان اخذ كرده و هماكنون استاديار دانشكاه آزاد اسلامى واحد كاشان است. زمينههاى يزوهشى مورد علاقهُ

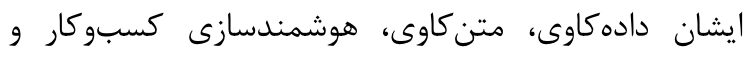

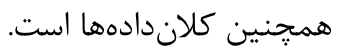

$$
\text { نشانى رايانامة ايشان عبارت است ادها است }
$$

\section{M.esmaeili@iaukashan.ac.ir}

$$
\begin{aligned}
& \text { [F] كرمى، مهتاب،" كاربرد ابزارهاى تحليلكر داده كاوى و } \\
& \text { متن كاوى درجابكى سازمان هاى مراقبت بهراشتى }
\end{aligned}
$$

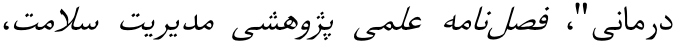

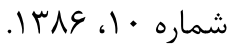

[4] M.Karami, Journal of Health Management,2008.

$$
\begin{aligned}
& \text { [ه] استيرى، احمد، كاهانى، محسن، قائمى، هادى، "ايجاد و }
\end{aligned}
$$

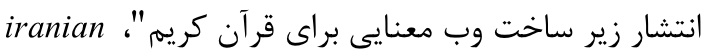

$$
\begin{aligned}
& \text { association of information and communication } \\
& r \cdot r \text {. technology }
\end{aligned}
$$

[5] E. K. G. Estiri, Kahani, Ghaemi, Creating and publishing semantic web infrastructure for the Holy Quran, iranian association of information and communication technology, 2013.

[6] chue, s., puteri nor, e. (2014). frequent pattern extraction in the tafseer of al-quran. factually of computer sience and information technology.

$$
\begin{aligned}
& \text { [V] }
\end{aligned}
$$

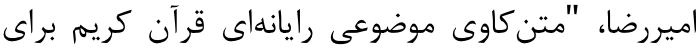

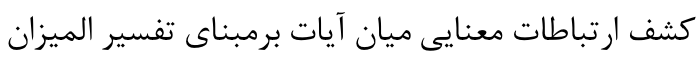

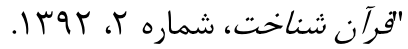

[7] S. M. A. Salehi Shahroodi, Minaie, Ashrafi,The text explores the computerized subject of the Holy Quran to discover the semantic connections between the verses based on the interpretation of alMizan. The Quran recognizes, pp 117-152,2013.

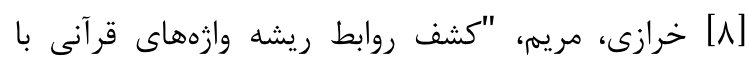
رويكرد دادهاوى"، دانشكاه خواجه نصيرالدين طوسى، رواني

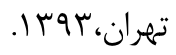

[8] K.Kharazi, Discover the root relationships of Quranic words with the data mining approach. Tehran: Khaje Naseerdin Tousi University, 2011.

[9] chua, s., nor ellyza biniti nohuddin, p. (2014). Frequent pattern extraction in the tafseer of al-quran. department of computer science.

[10] alhawarat, m., hegazi, m., hilal, a. (2015). processing the text of the holy quran: a text mining study. international journal of advanced science and applications, 262-26

[11] ali, i. (2012). application of a mining algorithm to finding frequent patterns in a text corous: a case study of the arabic. international journal of software engineering and its applications, 127-134.

[12] Nasreen, S., Awais Azam, M., Shehzad, K., Naeem, U., Ali Ghazanfar, M. (2014). Frequent pattern mining algorithms for finding associated frequent patterns for data streams: a survey. emerging ubiquitous systems and pervasive networks, 109-116 